\title{
Primary Energy Factor of a District Cooling System
}

\author{
Tjaša Duh Čož - Andrej Kitanovski - Alojz Poredoš \\ University of Ljubljana, Faculty of Mechanical Engineering, Slovenia
}

The primary energy efficiency for various energy-related processes can be calculated using the primary energy factor (PEF). In this paper, the PEFs of district cooling systems $\left(P E F_{D C}\right)$ for different types of cold production are derived. These concern cold production with an absorption chiller driven by different available sources and cold production with a compressor chiller driven by different types of engines and related energy sources. Based on the fundamental definition of the PEF, a mathematical model for calculating the $P E F_{D C}$ for different types of cold production was developed. The results in this study reveal that the $P E F_{D C}$ can be significantly improved in the case of combined cooling and power generation. The $P E F_{D C}$ in the case of combined cooling and power generation is lower than when cooling with electrically driven compressor chillers when the energy efficiency of the electricity generation in thermal power plant $\left(\eta_{e l}\right)$ is low or the PEF of the electricity $\left(P E F_{\text {el }}\right)$ is high. In cold production technologies where coal is used as the primary energy source more primary energy is consumed compared to other primary energy sources (i.e. natural gas, waste heat, etc.).

Keywords: primary energy factor, combined generation, district cooling, chiller

Highlights

- $\quad$ Primary energy factors (PEFs) appear in many legislations and research reports.

- $\quad P E F$ can be used to determine the primary energy consumption of cold production.

- $\quad$ This work provides mathematical model for calculation of PEFs for different cooling technologies.

- Moreover this work provides results of analysis of PEFs of district cooling systems.

- $\quad$ The PEFs of district cooling systems can be used for the selection of the most primary energy efficient cold production technology.

\section{O INTRODUCTION}

In the past decade, the EU has been taking a more active role in the field of improving energy efficiency, reducing energy consumption and exploiting renewable energy sources. In order to define the actual primary energy efficiency of various energy-related processes, the primary energy factor (PEF) can be used as a tool. The PEF enables a comparison between the input primary energy to the system and the energy delivered to the consumer. Its evaluation involves the energy required for the extracting, processing, storing and transporting to a power plant, energy conversion, transmission, distribution and the losses associated with these processes. The primary energy in this particular case includes the energy contained in the raw fuels as well as other forms of energy received as the input to the energy-supply system. It covers both renewable and non-renewable energy sources and the definition here is in accordance with EN 153164-5 [1], which states that '.. waste heat, surplus heat and regenerative heat sources are included with the appropriate primary energy factors.'

A set of directives has been approved in order to reduce the energy consumption, increase the efficiency and exploit renewable energy sources. The PEF has been used as a significant metric in order to calculate the actual primary energy efficiency of different processes in several legislations, i.e., in Directive 2012/27/EU on energy efficiency [2], Directive 2010/31/EU on the energy performance of buildings [3] and Directive 2009/28/EC on the promotion of the use of energy from renewable sources [4]. The essential requirements from those directives appear in the relevant European standards in order to implement the calculation of the energy efficiency and the PEF. Standard EN 15203/15315:2006 [5] presents the different values of the PEF provided by the Swiss Federal Institute of Technology. In the standards EN 15316-4-5:2006 [1] and EN 15603:2008 [6] the different values of the PEFs for various types of electricity generation are recommended. All the standards listed above use fixed values of the PEFs that are commonly not updated. However, PEFs are variable, because they depend on the specific mix of primary energy sources and the efficiency of the processes of generation, storage and transportation.

Beretta et al. [7] presented a method that provides a dynamic calculation of the PEF depending on the variation of time and geographical location. Laverge an Janssens [8] attempted to use empirical data to calculate the PEFs for a set of countries in a specific year. However, his study did not follow a complete and replicable methodology and it did not include the losses associated with generation, storage and transportation. Wilby et al. [9] claimed that fixed 
values of PEFs are not capable of representing the evolution of the energy system. He proposed an application to calculate dynamic PEFs based on empirical data. Among the 14 countries that were included in the study, 9 countries had real PEFs of electricity below the European average of 2.5 (Finland 1.32, Norway 1.39, Denmark 1.7, etc.) and the rest of the countries had values above the European average (Poland 2.91, France 3.4, etc.). Schicktanz et al. [10], Fumo and Chamra [11] and Mago and Chamra [12] used the PEF to calculate the primary energy consumption and energy costs of a combined heating, cooling and power system (trigeneration). Different PEFs from different types of district heating and cooling systems are presented by Wirgentius [13]. The renewable part of the primary energy was excluded from the study. Dalla Rosa and Christensen [14] presented the primary energy performance of a network that was designed for low-temperature operation. The calculations hypothesized PEFs of 2.5 for electricity and 0.8 for district heating. Prandin [15] used the PEFs to calculate the exergy consumption of a space heating system. Życzyńska [16] explored the methodology for determining the PEF of a specific urban heating system. The methodology was based on real measurements. A PEF of 0.5 (heat from cogeneration) was obtained in this study. Jungbauer et al. [17] presented measurements of the PEF of a district cooling system in Barcelona (0.6), Copenhagen (0.93), Helsinki (0.18), Gothenburg (0.44) and Vienna (0.62). Riepl et al. [18] used PEFs to calculate the primary energy savings using solar thermal cooling and heating plants with absorption chillers compared to electric vapour-compressor chiller systems.

The aim of this study is a development of a general mathematical model for the calculation of the $P E F_{D C}$. This mathematical model can be used as a tool in a feasibility study of a new district cooling system in order to select the cooling technology with the lowest $P E F_{D C}$. In this paper several different types of cold production are included in the calculation of the $P E F_{D C}$. This study concerns cold production with an absorption chiller driven by the heat from different available sources as well as cold production with a compressor chiller driven by different types of engines and related energy sources. A study of $P E F_{D C}$ in such a wide range of district cooling technologies has not yet been found in the literature.

\section{DEFINITION OF THE PEF OF A DISTRIC COOLING SYSTEM}

The primary energy efficiency of a district cooling system can be defined by evaluating the $P E F_{D C}$, which is the ratio between the primary energy input $Q_{P}$ and the cooling energy at the primary side of the substation $Q_{D C}$. The cooling energy $Q_{D C}$ in the Eq. (1) presents the sum of the cooling energy of all consumers connected to the district cooling system. The basic definition of the PEF for a district cooling system can be shown using the following expression:

$$
P E F_{D C}=Q_{P} / Q_{D C} \text {. }
$$

In the case of a trigeneration system only part of the fuel input is used for the cold production. The rest of it is used for the production of heat and electricity. Therefore, in the case of a district cooling system related to a trigeneration plant, the expression for PEF in Eq. (1) can be rearranged as [19]:

$$
\begin{aligned}
P E F_{D C} & =\frac{\sum_{i} Q_{F, i} \cdot P E F_{F}}{\sum_{k} Q_{D C, k}}- \\
& -\frac{\left(W_{e l} \cdot P E F_{e l}+\sum_{j} Q_{D H, j} \cdot P E F_{D H}\right)}{\sum_{k} Q_{D C, k}} .
\end{aligned}
$$

In the following text, the $P E F_{D C}$ for different types of cold production and different types of fuel input are determined. In this case the cooling-energy consumption of an absorption chiller is defined as:

$$
Q_{D C, a b s}=Q_{H} \cdot C O P_{a b s} \cdot \eta_{D N} .
$$

For the compressor chiller, the cooling-energy consumption is defined as:

$$
Q_{D C, \text { com }}=W_{e l} \cdot C O P_{c o m} \cdot \eta_{D N} .
$$

Fig. 1 illustrates the different types of cold production that are analyzed in this paper. Cold can be produced either by a compressor or by absorption chillers. Different types of absorption chillers can be used: a single-effect absorption chiller (SEAC) driven by hot water, a double-effect absorption chiller (DEAC) driven by steam and a direct-fired absorption chiller (DFAC) driven by natural gas. Waste heat (WH) from an industrial process can also be used to drive an absorption chiller. Compressor chillers are divided into two groups: compressor chillers driven by an electric motor (CC) and compressor chillers driven by an internal combustion engine (ICE). In this study, the primary energy consumption of the cooling towers is not included in the calculation of the $P E F_{D C}$.

The technical parameters of the chillers are presented in Table 2 . 


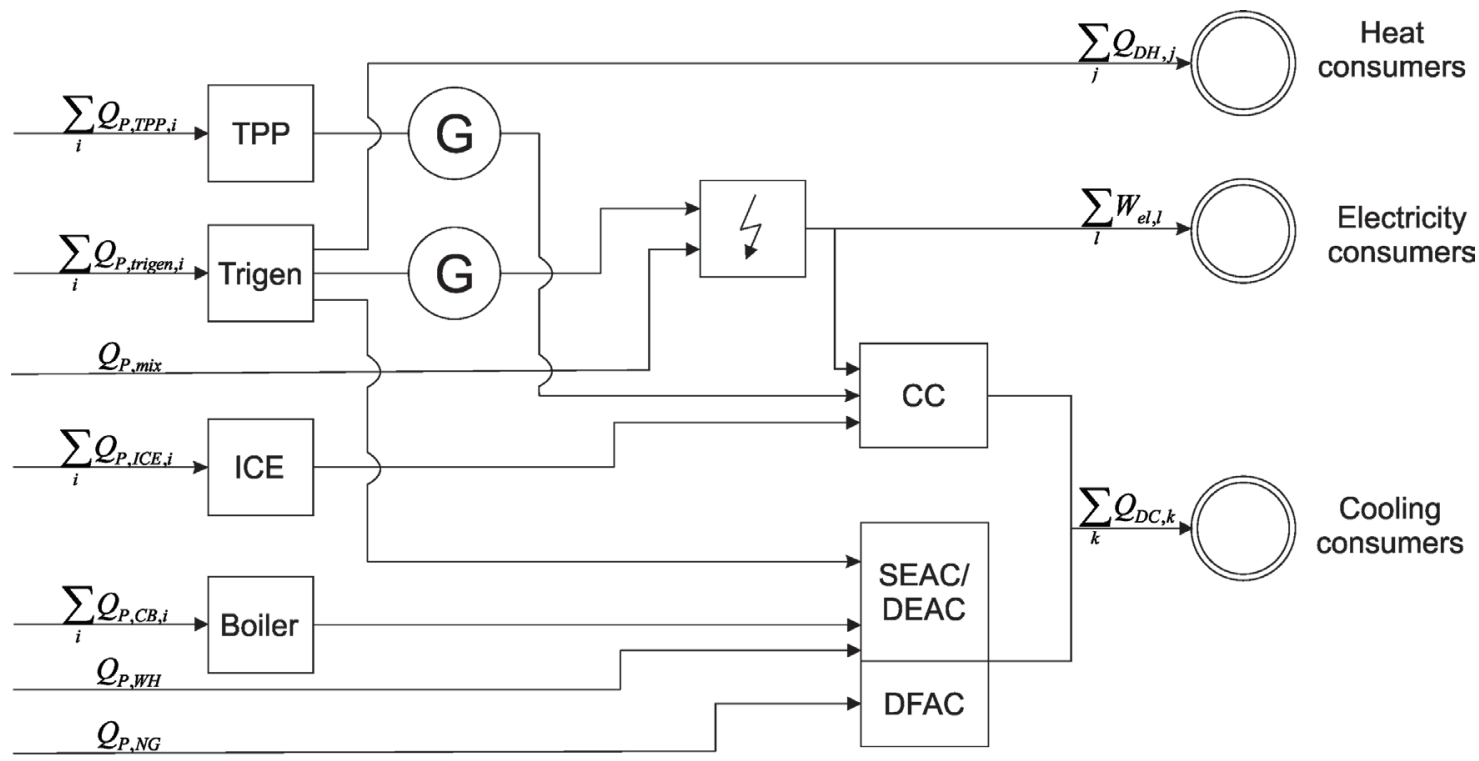

Fig. 1. The different types of cold production included in this study

\subsection{Cold Production with an Absorption Chiller Driven by the Heat from a Boiler (CB)}

The heat from the combustion of fuel in a boiler drives the absorption chiller. A single- or doubleeffect absorption chiller can be used to produce cold. The primary energy consumption is:

$$
Q_{P, C B}=\frac{Q_{H}}{\eta_{C B}} \cdot P E F_{F} .
$$

The PEF of a district cooling system for this particular case can be defined by using Eqs. (3) and (5) in Eq. (1):

$$
P E F_{D C, C B}=\left(\frac{1}{C O P_{a b s} \cdot \eta_{D N} \cdot \eta_{C B}}\right) \cdot P E F_{F} .
$$

Coal and natural gas are considered as fossil fuels in this study. According to [1], the $P E F_{\text {coal }}=1.3$, and for natural gas, the $P E F_{N G}=1.1$ (see also Table 1).

\subsection{Cold Production with a Direct-Fired Absorption Chiller Driven by Natural Gas (DFAC $\mathrm{NG}_{\mathrm{N}}$ )}

A direct-fired absorption chiller is driven by the heat from the combustion of natural gas. According to Makita [20], the COP of a direct-fired absorption chiller is defined as:

$$
C O P_{D F A C}=Q_{C} / Q_{L H V} .
$$

The primary energy consumption of a direct-fired absorption chiller is calculated as:

$$
Q_{P, N G}=Q_{L H V} \cdot P E F_{N G} .
$$

Using Eqs. (1), (7) and (8), the PEF of a district cooling system can be defined as:

$$
P E F_{D C, N G}=\left(\frac{1}{C O P_{D F A C} \cdot \eta_{D N}}\right) \cdot P E F_{N G} .
$$

The $P E F_{N G}$ is given in Section 1.1 (see also Table 1).

\subsection{Cold Production with an Absorption Chiller Driven by Waste Heat from an Industrial Process (WH)}

In the case of a district cooling system consisting of an absorption chiller driven by the waste heat from an industrial process, the primary energy consumption is calculated as follows:

$$
Q_{P, W H}=Q_{H} \cdot P E F_{W H} .
$$

The heat delivered to the absorption chiller can be effluent, hot water or steam. Using Eqs. (1), (3) and (10), the PEF of the waste heat from the industrial process is:

$$
P E F_{D C, W H}=\left(\frac{1}{C O P_{a b s} \cdot \eta_{D N}}\right) \cdot P E F_{W H} .
$$

The waste heat includes the heat from municipal incineration and industrial surplus heat. The PEF of the waste heat is defined according to Refs. [21] and [22] as $P E F_{W H}=0.05$ (see also Table 1). Using waste heat 
to drive an absorption chiller avoids the use of fossil fuels and make use of the energy flows that otherwise would be lost. Hence, the value of the PEF is almost 0 . When calculating the $P E F_{D C}$ that uses waste heat to drive an absorption chiller, it is necessary to take into account that heat with different parameters (see Table 2 ) is used.

\subsection{Cold Production with a Compressor Chiller Driven by the Electricity from the Grid $\left(\mathrm{CC}_{\text {mix }}\right)$}

Different energy sources can be used to generate electricity. This is then further used to drive the motor of the compressor chiller.

The primary energy consumption of an electrically driven compressor chiller is:

$$
Q_{P, \text { mix }}=W_{e l} \cdot P E F_{e l, m i x} .
$$

Using Eqs. (4) and (12), Eq. (1) can be rewritten as:

$$
P E F_{D C, C C_{\text {mix }}}=\left(\frac{1}{C O P_{c o m} \cdot \eta_{D N}}\right) \cdot P E F_{e l, m i x} .
$$

The PEF of the electricity from the grid is defined according to Ref. [14] as $P E F_{e l, m i x}=2.5$. This value represents the European average. Each country has the right to set a different value for its $P E F_{\text {el,mix }}$, providing its choice is adequately justified (see also Section 0 ).

\subsection{Cold Production with a Compressor Chiller Driven by the Electricity Generated in a Thermal Power Plant ( CC $\left._{\text {TPP }}\right)$}

Since the electricity from thermal power plants (TPP) represents only a part of the electricity mix, the electricity produced in the thermal power plant is discussed separately.

In this subsection a compressor chiller driven by the electricity from a thermal power plant (TPP) is studied. Two different scenarios are discussed: a compressor chiller driven by the electricity generated in a generator, connected to a steam turbine (combustion of coal), and a compressor chiller driven by electricity, where the generator is connected to a combined cycle of gas and steam turbine (combustion of natural gas).

The primary energy consumption of the electrically driven compressor chiller is calculated as:

$$
Q_{P, T P P}=\frac{W_{e l}}{\eta_{e l}} \cdot P E F_{F} .
$$

The PEF of a district cooling system with an electrically driven compressor chiller (electricity produced in a thermal power plant) is calculated using Eqs. (1), (4) and (14):

$$
P E F_{D C, C C_{T P P}}=\left(\frac{1}{C O P_{c o m} \cdot \eta_{D N} \cdot \eta_{e l}}\right) \cdot P E F_{F} .
$$

The $P E F_{F}$ are given in Section 1.1 (see also Table $1)$.

\subsection{Cold Production with a Compressor Chiller Driven by an Internal Combustion Engine (CC ${ }_{\text {ICE }}$ )}

This kind of system consists of a compressor chiller that is driven by the mechanical energy produced with an internal combustion engine (ICE). According to Yingjian [23], the COP of an engine-driven compressor chiller is defined as:

$$
C O P_{\text {com }, I C E}=Q_{C} / W_{m e} .
$$

The primary energy consumption of an enginedriven compressor chiller is:

$$
Q_{P, I C E}=W_{m e} \cdot P E F_{F} .
$$

Using Eq. (4), (16) and (17), Eq. (1) can be rewritten as:

$$
P E F_{D C, C C_{I C E}}=\left(\frac{1}{C O P_{C o m, I C E} \cdot \eta_{D N}}\right) \cdot P E F_{F} .
$$

The ICE can be driven by diesel, petrol, kerosene or natural gas; the values for the PEF of the fuel are defined according to [1] and [24] (see also Table 1).

\subsection{Cold Production in Combined Cooling and Power Generation (CCP)}

A trigeneration system (combined cooling, heating and power generation) is a combination of a cogeneration plant and an absorption chiller (see Fig. 1). In such a system where the cooling energy is produced with absorption chillers driven by heat, the steam should be extracted from an extraction-condensing turbine using the parameters that are required for the chiller's normal operation (see the parameters in Table 2). Consequently, the generation of electrical energy is reduced, and more primary energy is consumed in order to produce the same amount of electrical energy as in the case of a condensing turbine regime. In this subchapter the combined cooling and power generation is considered. It is assumed that all the available heat from a thermal power plant is used to produce cold. Therefore, the district heat consumption $Q_{D H}$ in Eq. (2) is equal to 0. 
To calculate the $P E F_{D C}$ based on combined cooling and power generation (CCP) the Eq. (2) can be rearranged to:

$$
P E F_{D C, C C P}=\frac{\Delta Q_{F} \cdot P E F_{F}}{C O P_{a b s} \cdot \eta_{D N}} \cdot \frac{1}{\left(\eta_{C C P, \text { total }}-\eta_{C C P, e l}\right)},
$$

where $\Delta Q_{F}$ presents the difference between the energy consumption of fuel, when both, electricity and cold are produced (i.e. CCP) and when only electrical energy is produced in thermal power plant (TPP) (see the Eq. (20)). In both cases the amount of produced electrical energy remains the same $\left(W_{e l}=W_{e l, T T P}=W_{e l, C C P}\right)$.

$$
\Delta Q_{F}=Q_{F, C C P}-Q_{F, T P P}=W_{e l}\left(\frac{1}{\eta_{C C P, e l}}-\frac{1}{\eta_{e l}}\right) .
$$

The PEF of a district cooling system where all the available heat from plant is used in an absorption chiller to produce the cooling energy is calculated using Eqs. (3), (19) and (20):

$$
P E F_{D C, C C P}=\frac{P E F_{F} \cdot(1-x)}{C O P_{a b s} \cdot \eta_{D N}} \cdot \frac{1}{\left(\eta_{C C P, \text { total }}-\eta_{C C P, e l}\right)},
$$

where

$$
x=\eta_{C C P, e l} / \eta_{e l},
$$

is the ratio between the energy efficiency of the electricity generation in a combined cooling and power generation system $\eta_{C C P, e l}$ (heat and power production; heat is extracted from an extraction-condensing turbine) and the energy efficiency of the electricity generation in a thermal power plant when operation is related only to the production of electricity $\eta_{e l}$ (power production; condensing turbine). The total energy efficiency of a cogeneration system where all the extracted heat is used for cold production is $\eta_{C C P, \text { total }}$. Only natural gas and coal are considered as the fuels in this study. The $P E F_{F}$ are given in Section 1.1.

\section{PARAMETERS USED IN THIS ANALYSIS}

Based on the equations from Section 1 a mathematical model was developed. The parameters used in this model are divided into two categories:

- Primary energy factors $\left(P E F_{D C}, P E F_{e l}, P E F_{F}\right.$ $\left(P E F_{\text {coal }}, P E F_{N G}, P E F_{W H}\right)$ ).

- Technical parameters $\left(\eta_{C B}, \eta_{D N}, \eta_{e l}, \eta_{C C P, e l}\right.$, $\left.\eta_{C C P, \text { total }}, C O P_{a b s}, C O P_{D F A C}, C O P_{\text {com }}, C O P_{\text {com, ICE }}\right)$. The PEFs of the fuels considered in this study are shown in Table 1.

Table 1. Primary energy factors of fuels

\begin{tabular}{lcc}
\hline Fuel & PEF & Ref. \\
\hline Coal & 1.3 & {$[1]$} \\
\hline Natural gas & 1.1 & {$[1]$} \\
\hline Oil & 1.1 & {$[1]$} \\
\hline Heat from combined gas and steam turbine & 0.5 & {$[25]$} \\
\hline Heat from steam turbine & 0.8 & {$[14]$ and [25] } \\
\hline Waste heat from industrial process & 0.05 & {$[21]$ and [22] } \\
\hline Electricity (EU average) & 2.5 & {$[14]$} \\
\hline Diesel, petrol, kerosene & 1.19 & {$[24]$} \\
\hline
\end{tabular}

Table 2 shows the technical parameters of the chillers considered in this study. The calculations for the $P E F_{D C}$ were made for a single-effect absorption chiller driven by hot water, a double-effect absorption chiller driven by steam, and a direct-fired absorption chiller driven by natural gas or the waste heat from an industrial process. The electrically driven and enginedriven compressor chillers were also included in this study.

In the literature the COPs of different types of chillers were presented at given conditions: for gas absorption and engine-driven compressor chiller the chilled water temperature was $7^{\circ} \mathrm{C}$. The cooling water inlet temperature was $32{ }^{\circ} \mathrm{C}$ for DFAC and $30{ }^{\circ} \mathrm{C}$ for ICE. For all other types of chillers the chilled

\begin{tabular}{|c|c|c|c|c|c|c|}
\hline Chiller & $\begin{array}{c}\text { Cooling } \\
\text { power } \\
{[\mathrm{kW}]}\end{array}$ & $\begin{array}{c}\text { Chilled water } \\
\text { temperature } \\
{\left[{ }^{\circ} \mathrm{C}\right]}\end{array}$ & $\begin{array}{c}\text { Cooled water } \\
\text { inlet temperature } \\
{\left[{ }^{\circ} \mathrm{C}\right]}\end{array}$ & Driving energy & COP & Ref. \\
\hline Steam absorption (DEAC) & 2000 & 6 & 32 & 8 bar steam & $C O P=Q_{C} / Q_{H}=1.39$ & [26] \\
\hline Hot water absorption (SEAC) & 2000 & 6 & 32 & $98^{\circ} \mathrm{C}$ hot water & $C O P=Q_{C} / Q_{H}=0.79$ & [26] \\
\hline Gas absorption (DFAC) & $\begin{array}{l}282 \text { to } \\
2462\end{array}$ & 7 & 32 & $\begin{array}{c}\text { Natural gas } \\
\left(L H V=34 \mathrm{MJ} / \mathrm{Sm}^{3}\right)\end{array}$ & $C O P=Q_{C} / Q_{L H V}=1.42$ & [20] \\
\hline Compressor chiller & 2000 & 6 & 32 & Electricity & $C O P=Q_{C} / W_{e l}=6.6$ & [26] and [27] \\
\hline $\begin{array}{l}\text { Engine-driven compressor } \\
\text { chiller (ICE) }\end{array}$ & 140 & 7 & 30 & Fossil fuels & $C O P=Q_{C} / W_{m e}=2.7$ & [24] and [28] \\
\hline
\end{tabular}
water temperature was $6^{\circ} \mathrm{C}$ and cooling water inlet temperature $32{ }^{\circ} \mathrm{C}$.

Table 2. Data for the selected chillers 
The following energy efficiencies were used in this study [29] to [34]: the total energy efficiency of a combined cooling and power generation system $\left(\eta_{C C \text {, total }}\right)$, the boiler efficiency $\left(\eta_{C B}\right)$ and the energy efficiency of a district network $\left(\eta_{D N}\right)$. For the purpose of the study they are all assumed to be 0.9. Energy efficiency of the network considers heat gains which affect the primary energy consumption; therefore, more primary energy has to be used to provide the required cooling demand.

\section{RESULTS AND DISCUSSIONS}

Based on the parametric analysis, introduced in Section 1, this section provides the values for the PEF of a district cooling system $\left(P E F_{D C}\right)$ for different types of cold production as a function of:

- the $C O P$ of absorption or compressor chillers $\left(C O P_{a b s}, C O P_{c o m}\right)$,

- the PEF of the electricity $\left(P E F_{e l}\right)$,

- the energy efficiency of the electricity generation when operation is related only to the production of electricity $\left(\eta_{e l}\right)$.

In this study the ratios $x$ in Eq. (22) are set as 0.95 when single effect absorption chiller is used for cold production and 0.92 or 0.90 when double effect absorption chiller is used. The values of the PEF for the electricity mix considered in this study are 2.5 [17] and 1.3 [9]. The $P E F_{D C}$ in Sections 3.1 and 3.2 were calculated for a constant energy efficiency of the electricity generation when operation is related only to the production of electricity: $\eta_{e l}=0.37$ for a steam turbine and $\eta_{e l}=0.55$ for a combined cycle of gas and steam turbine.

The COP is highly dependent on operating conditions. The operating conditions are considered in this study indirectly in Sections 3.1 and 3.2, where the $P E F_{D C}$ as a function of COPs is presented.

\section{1 $P E F_{D C}$ as a Function of the COP for the Absorption Chiller}

The PEF of a district cooling system $\left(P E F_{D C}\right)$ as a function of the $\mathrm{COP}$ of an absorption chiller $\left(C O P_{a b s}\right)$ is presented in Fig. 2. In this case, different types of cooling with an absorption chiller were evaluated:

- cooling with an absorption chiller driven by heat from a boiler, where coal $\left(C B_{\text {coal }}\right)$ and natural gas $\left(C B_{N G}\right)$ are used as the fuel,

- cooling with a direct-fired absorption chiller where natural gas $\left(D F A C_{N G}\right)$ is used as the fuel,

- cooling with an absorption chiller driven by waste heat from an industrial process,

- cooling with combined cooling and power generation, where coal $\left(C C P_{\text {coal }, x=0.95, \eta_{e l}=0.37}\right)$ and natural gas $\left(C C P_{N G, x=0.95, \eta_{l l}=0.55}\right)$ are used as the fuel.

In this Section the ratio $x$ remains the same $(x=0.95)$ for all the values of the $C O P_{a b s}$. In the following subsections the different values of the ratio $x$, as a consequence of the different parameters of the heat extracted from the extraction-condensing turbine, are taken into account.

As can be seen from Fig. 2, the $P E F_{D C}$ decreases with an increase of the $C_{\text {abs }}$ (since less heat is required to drive the absorption chiller). The highest value of the $P E F_{D C}$ is achieved when the absorption chiller is driven by the heat from a boiler and when coal is used as the fuel $\left(C B_{\text {coal }}\right)$. For this particular case the $P E F_{D C}=2.53$ for the absorption chiller with the $C O P=0.6$ and the $P E F_{D C}=1.09$ for the absorption chiller with the $C O P=1.4$.

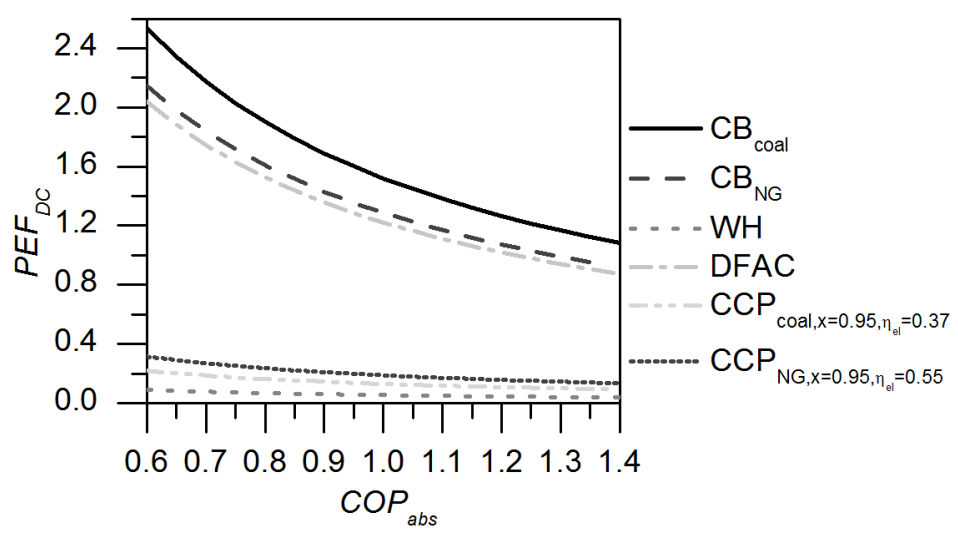

Fig. 2. Primary energy factor of a district cooling system as a function of the COP for an absorption chiller 
The $P E F_{D C}$ can certainly be improved in the case of combined cooling and power generation (CCP - a CHP plant where all amount of heat is used to drive absorption chillers). For instance, when coal (i.e. case $\left.\mathrm{CCP}_{\text {coal }}\right)$ is used as the primary energy source in such a plant, the $P E F_{D C}=0.22$ (for the $C O P=0.6$ ) and the $P E F_{D C}=0.09$ (for the $C O P=1.4$ ). When natural gas (i.e. case $\mathrm{CCP}_{\mathrm{NG}}$ ) is considered as the primary energy source, the $P E F_{D C}=0.27$ (for the $C O P=0.6$ ) and to $P E F_{D C}=0.12$ (for the $C O P=1.4$ ). The lowest value of $P E F_{D C}$ is achieved when the absorption chiller is driven by waste heat from the industrial process.

\section{2 $\mathrm{PEF}_{D C}$ as a Function of the COP for the Electrically Driven Compressor Chiller}

The $\mathrm{PEF}_{\mathrm{DC}}$ as a function of the $\mathrm{COP}$ for an electrically driven compressor chiller $\left(C O P_{\text {com }}\right)$ is shown in Fig. 3. In this case different types of cooling with a compressor chiller were evaluated:

- cooling with a compressor chiller driven by electricity mix from the grid $\left(\mathrm{CC}_{\text {mix }}\right)$,

- cooling with a compressor chiller driven by electricity generated in a thermal power plant, where coal $\left(C C_{T P P, \text { coal }, \eta_{e l}=0.37}\right.$ and $\left.C C_{T P P, \text { coal }, \eta_{e l}=0.45}\right)$ and natural gas are used as the fuel $\left(C C_{T P P, N G, \eta_{e l}=0.55}\right.$ and $\left.C C_{T P P, N G, \eta_{e l}=0.60}\right)$.

From the results in Fig. 3 it is clear that the lowest values of the $P E F_{D C}$ are achieved when a compressor chiller driven by electricity mix from the grid $\left(P E F_{e l}=1.3\right)$ is used. For this particular case $P E F_{D C}=0.36$ (for the $C O P_{c o m}=4$ ) and $P E F_{D C}=0.18$ (for the $C O P_{c o m}=8$ ). In the case when the compressor chiller is driven by electricity from a thermal power plant (combined cycle of gas and steam turbine; natural gas is used as the fuel), $P E F_{D C}=0.56$ (for the $C O P_{\text {com }}=4$ ) and $P E F_{D C}=0.28$ (for the $C O P_{\text {com }}=8$ ) when $\eta_{e l}=0.55$. When $\eta_{e l}=0.60$, the $P E F_{D C}$ for this case decrease to $P E F_{D C}=0.51$ (for the $C O P_{\text {com }}=4$ ) and $P E F_{D C}=0.25$ (for the $C O P_{c o m}=8$ ). The highest values of $P E F_{D C}$ are achieved when the cold is produced by a compressor chiller driven by electricity generated in a thermal power plant with $\eta_{e l}=0.37$ where coal is used as the primary energy source $\left(C C_{T P P, c o a l, \eta_{e l}=0.37}\right)$.

\section{3 $P E F_{D C}$ as a Function of the PEF for Electricity}

Fig. 4 shows the $P E F_{D C}$ depending on the PEF of electricity $\left(P E F_{e l}\right)$ for the typical COPs for the absorption and compressor chillers given in Table 2. Different types of cold production were considered in this analysis:

- the cold production by an electrically driven compressor chiller $\left(\mathrm{CC}_{\text {mix }}\right)$; the $P E F_{\text {el,mix }}$ ranges from 1.3 to 3.5 ,

- the cold production by an engine-driven compressor chiller $\left(\mathrm{CC}_{\mathrm{ICE}}\right)$,

- the cold production by single- and double-effect absorption chillers; absorption chillers driven by the heat from a steam turbine; $\left(\mathrm{CCP}_{\mathrm{SEAC} \text {,coal }}\right.$, $\left.\mathrm{CCP}_{\mathrm{DEAC}, \text { coal }}\right)$; the $\eta_{e l}$ of a steam turbine ranges from 0.32 to 0.45 and consequently the $P E F_{e l}$ of a steam turbine ranges from 2.9 to 4 ,

- the cold production by single- and doubleeffect absorption chillers driven by the heat from a combined cycle of gas and steam turbine $\left(\mathrm{CCP}_{\mathrm{SEAC}, \mathrm{NG}}, \mathrm{CCP}_{\mathrm{DEAC}, \mathrm{NG}}\right)$; the $\eta_{e l}$ ranges from 0.35 to 0.60 and consequently the $P E F_{e l}$ of a gas and steam turbine ranges from 1.8 to 3.1 .

From the results in Fig. 4 it is clear that the $P E F_{D C}$ system decreases when increasing the $P E F_{e l}$ of the thermal power plant in the case when absorption chillers are used to produce the cold. The $P E F_{e l}$ of

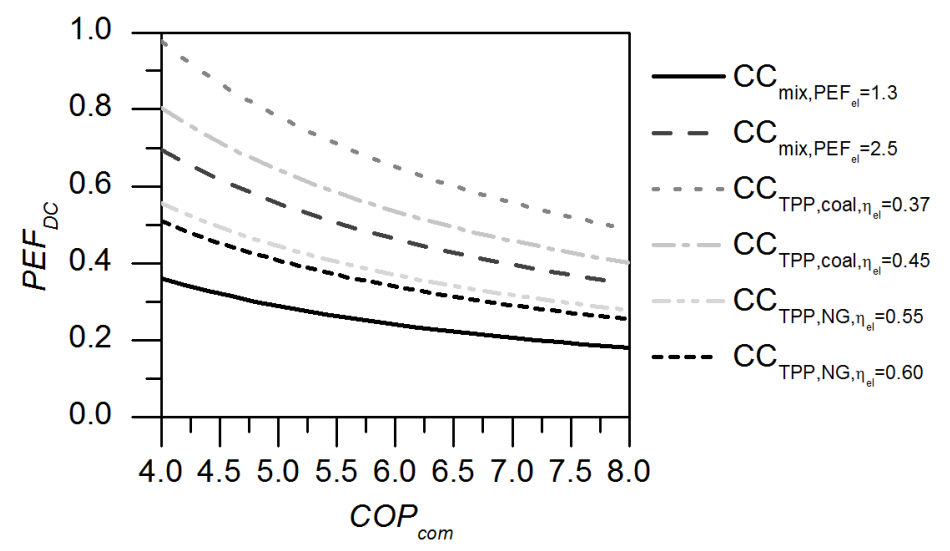

Fig. 3. Primary energy factor of a district cooling system as function of the COP for an electrically driven compressor chiller 


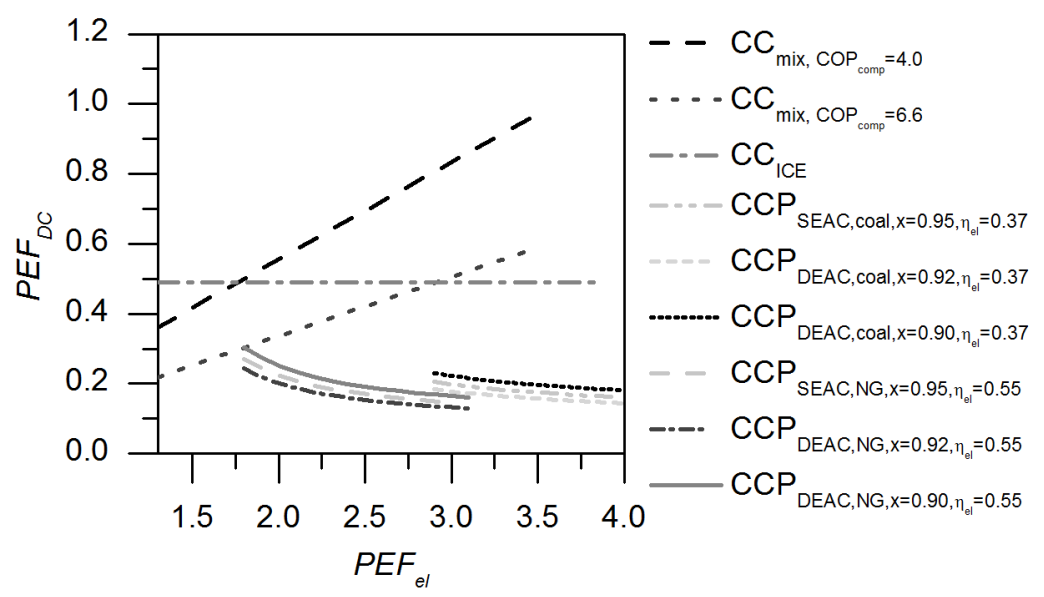

Fig. 4. Primary energy factor of a district cooling system as a function of the primary energy factors of electricity for different chillers

the thermal power plant is inversely proportional to the energy efficiency of the electricity generation $\left(P E F_{e l}=P E F_{F} / \eta_{e l}\right)$; therefore, by decreasing the $\eta_{e l}$, the $\mathrm{PEF}_{\mathrm{DC}}$ decreases. In the case of electrically driven compressor chiller the $P E F_{D C}$ increases when increasing the $P E F_{e l}$.

The $P E F_{\text {el }}$ does not affect the $P E F_{D C}$ when an engine-driven compressor chiller $\left(\mathrm{CC}_{\mathrm{ICE}}\right)$ is used (because this particular compressor chiller is directly driven by mechanical energy, i.e., no electricity is used). In this particular case the $P E F_{D C}$ can be considered as constant $\left(P E F_{D C, I C E}=0.49\right)$. Therefore, when the $P E F_{e l}>2.9$, the primary energy consumption is lower in the case of an engine-driven compressor chiller, compared to an electrically driven compressor chiller $\left(P E F_{C C_{C E}}<P E F_{C C, m i x}\right)$.

The $P E F_{D C}$ of the electrically driven compressor chiller $\left(C_{\text {mix }}\right)$ increases from $P E F_{D C}=0.22$ (at $P E F_{e l}=1.3$ ) to $P E F_{D C}=0.59$ (at $P E F_{e l}=3.5$ ).

The lowest value for the $P E F_{D C}$ is achieved when a double-effect absorption chiller $(x=0.92)$, driven by the heat from a combined cycle of gas and steam turbine, is used $\left(\mathrm{CCP}_{\mathrm{DEAC}, \mathrm{NG}, x=0.92}\right)$. For this example $P E F_{D C}=0.24$ (at $\eta_{e l}=0.6$ and $P E F_{e l}=1.8$ ) and $P E F_{D C}=0.13$ (at $\eta_{e l}=0.35$ and $P E F_{e l}=3.1$ ). If ratio $x$ for double effect absorption chiller is lower $(x=0.9)$, the $P E F_{D C}$ increases and is even higher compared to $P E F_{D C}$ when single effect absorption chiller is used.

The energy efficiency of the electricity generation using the steam turbine, when operation is related only to the production of electricity, ranges from 0.32 to 0.45 . The lower the $\eta_{e l}$, the lower is the $P E F_{D C}$. For this particular case the lowest $P E F_{D C}=0.18$ is achieved at $\eta_{e l}=0.35$ when double effect absorption chiller $(x=0.92)$ is used.

\section{4 $P E F_{D C}$ as a Function of the Energy Efficiency of Electricity Generation in a Thermal Power Plant}

The aim of this subsection is to provide information about the $P E F_{D C}$ as a function of the energy efficiency of electricity generation in a thermal power plant, when operation is related only to the production of electricity $\left(\eta_{e l}\right)$. In Fig. 5a, the condensing steam turbine (coal is used as the primary energy source) is illustrated when a compressor chiller is driven by the electricity from the thermal power plant, and an extraction-condensing steam turbine is illustrated when absorption chillers are used. In Fig. $5 b$ the combined cycle of gas and steam turbine is taken into account (natural gas is used as the primary energy source).

As is clear from both examples in Fig. 5, the $P E F_{D C}$ is the lowest when a double-effect absorption chiller $\left(\mathrm{CCP}_{\mathrm{DEAC}, \mathrm{x}=0.92}\right)$ is used to produce the cold. The $P E F_{D C}$, with a compressor chiller driven by electricity from the grid $\left(\mathrm{CC}_{\text {mix }}\right)$, does not depend on the energy efficiency of the thermal power plant $\left(\eta_{e l}\right)$. In this particular case, it remains constant $\left(P E F_{D C}=0.42\right.$ at $P E F_{e l}=2.5$ and $P E F_{D C}=0.22$ at $\left.P E F_{e l}=1.3\right)$. By increasing the value of the $\eta_{e l}$ the $P E F_{D C}$ decreases when a compressor chiller driven by electricity from a thermal power plant $\left(\mathrm{CC}_{\mathrm{TPP}}\right)$ is used.

From the results in Fig. 5a, the $\mathrm{PEF}_{\mathrm{DC}}$ with a single-effect absorption chiller $\left(\mathrm{CCP}_{\mathrm{SEAC}, \mathrm{coal}, \mathrm{x}=0.95}\right)$ and double-effect absorption chillers $\left(\mathrm{CCP}_{\mathrm{DEAC}, \mathrm{coal}, \mathrm{x}=0.92}\right.$ and $\left.\mathrm{CCP}_{\mathrm{DEAC}, \text { coal }, \mathrm{x}=0.90}\right)$ are lower, compared to electrically driven compressor chillers $\left(\mathrm{CC}_{\text {mix }}\right.$ and $\mathrm{CC}_{\mathrm{TPP}}$ ), for any value of $\eta_{e l}$ at given ratios $\mathrm{x}$.

Analysing the results from Fig. 5b, the $P E F_{D C}$ with a compressor chiller driven by electricity from 


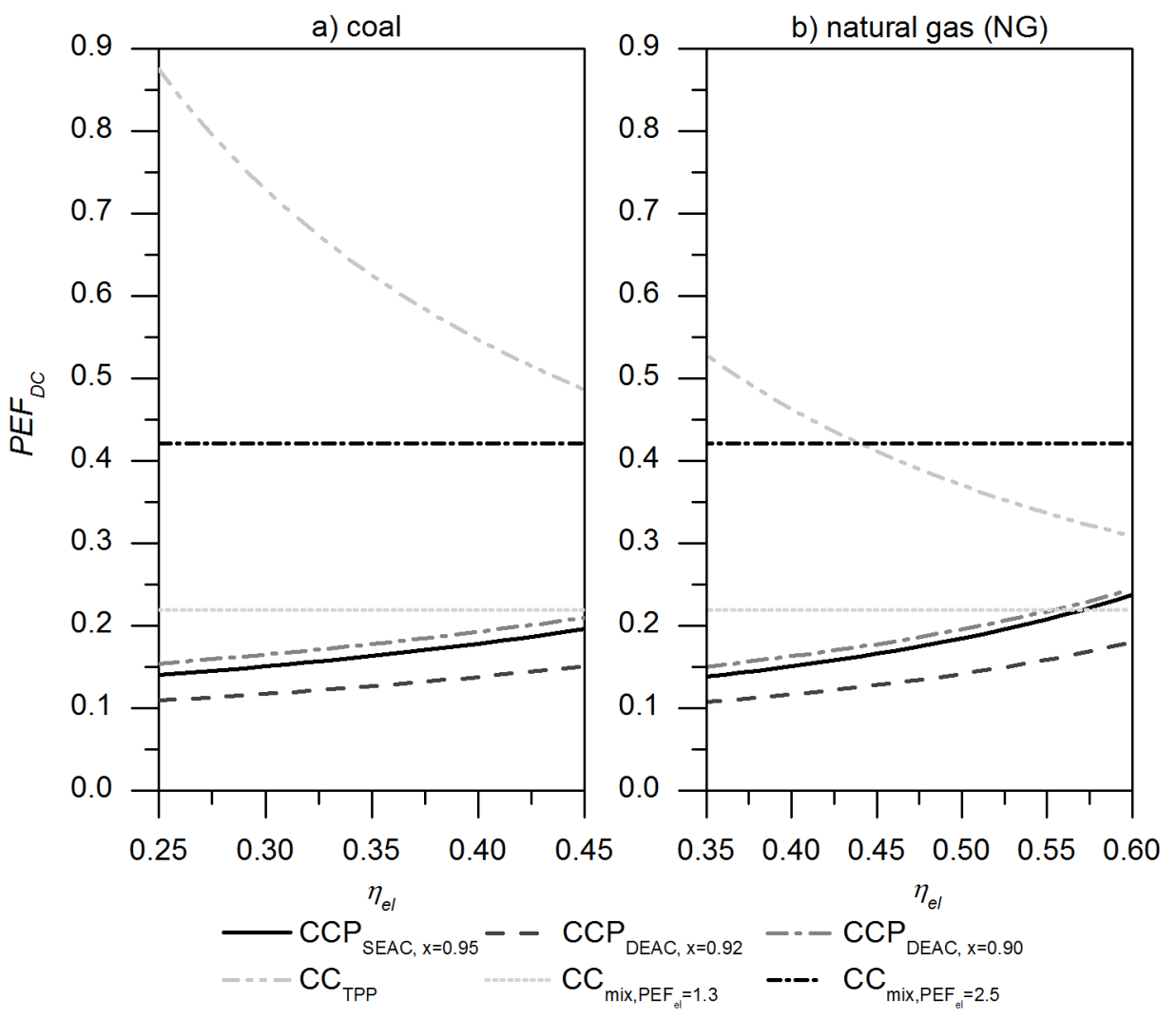

Fig. 5. Primary energy factors for a district cooling system as a function of the energy efficiency of the electricity generation in a thermal power plant: a) steam turbine (coal), b) combined cycle of gas and steam turbine (natural gas)

a thermal power plant is lower, compared with the one driven by the electricity mix $\left(P E F_{e l}=2.5\right)$ when $\eta_{e l}>0.44$. In the case of cold production with a single-effect absorption chiller $\left(\mathrm{CCP}_{\mathrm{SEAC}, \mathrm{NG}, \mathrm{x}=0.95}\right)$, the $P E F_{D C}$ is lower compared to electrically driven compressor chiller $\left(P E F_{e l}=1.3\right)$ until $\eta_{e l}>0.57$. Using the double-effect absorption chiller with $x=0.92$, the $P E F_{D C}$ are lower compared to any electrically driven compressor chiller for any value of $\eta_{e l}$. When double effect absorption chiller with $x=0.90$ is used, the $P E F_{D C}$ is lower compared to the compressor chiller driven by electricity from the grid $\left(P E F_{e l}=1.3\right)$ when $\eta_{e l}<0.55$.

\section{CONCLUSIONS}

In this paper an analysis of the primary energy factors of district cooling systems $\left(P E F_{D C}\right)$ for different types of cold production is presented. Several different types of chillers were included in the study: a single-effect absorption chiller, a double-effect absorption chiller, a direct-fired absorption chiller and a compressor chiller driven by electrical energy or by mechanical energy from an internal combustion engine. The PEFs of the different fuels were taken from earlier studies.

The results of the study reveal that:

- The most primary energy of all the cases discussed in this study is consumed for cold production with an absorption chiller driven by the heat from a boiler (see Fig. 2).

- Cold production with an engine-driven compressor chiller (ICE) compared to an electrically driven compressor chiller $\left(\mathrm{CC}_{\text {mix }}\right)$ is rational only if the $P E F_{e l}>2.9$ (see Fig. 4).

- Primary energy consumption can be reduced by using heat from CHP plant to drive absorption chillers (heat and electricity are produced in a CHP plant; all of the heat is used for the cold production). The lower the energy efficiency of electricity generation in a thermal power plant $\left(\eta_{e l}\right)$, the lower is the $P E F_{D C}$ (see Fig. 5).

- If the energy efficiency of electricity generation in a thermal power plant with a combined cycle of gas and steam turbine is higher than 0.44 , the $P E F_{D C}$ is lower for a compressor chiller driven by electricity from a thermal power plant $\left(\mathrm{CC}_{\mathrm{TPP}, \mathrm{NG}}\right)$ 
, compared to a compressor chiller driven by electricity from the grid with $P E F_{e l}=2.5$ (see Fig. 4). The $P E F_{D C}$ of a thermal power plant with a combined cycle of gas and steam turbine achieve its lowest value when $\eta_{e l}=0.6\left(P E F_{D C}=0.31\right)$.

- The heat extracted from the turbine affects the energy efficiency of electricity generation in a CHP plant. When a double-effect absorption chiller is used to produce cold, the energy efficiency of the electricity generation is lower compared to the energy efficiency of electricity generation when the heat to drive a singleeffect absorption chiller is extracted. The ratio $\mathrm{x}$, between the energy efficiency of electricity generation in a CHP plant (the heat is extracted from the extraction-condensing turbine) and the energy efficiency of electricity generation in a thermal power plant (condensing turbine) has a significant impact on the $P E F_{D C}$ (see Fig. 5).

- The comparison between the primary energy consumption of different cooling technologies and the cooling with electrically driven compressor chiller when $P E F_{e l}=2.5$ is presented in Appendix A.

The general mathematical model developed in this study can be used as a tool for selecting the most primary energy efficient type of cooling technology in a feasibility study of a new district cooling system implementation. In the future work this mathematical model has to be improved by considering the production of the electricity, heat and cold at the same time (trigeneration system). A very complex general mathematical model for the calculation of the $P E F_{D C}$ will have to take into account the ratio between the heat used for heating and the heat used for cold production. Moreover, it will consider the increase of the consumption of the primary energy as a consequence of heat extraction from the turbine and lastly, the primary energy consumption as a consequence of different parameters of the extracted steam has to be taken into the consideration.

\section{NOMENCLATURE}

$\begin{array}{ll}C O P & \text { coefficient of performance, [-] } \\ P E F & \text { primary energy factor, [-] } \\ Q & \text { energy, [kWh] } \\ W & \text { work, }[\mathrm{kWh}] \\ \eta & \text { energy efficiency, [-] }\end{array}$

\section{Abbreviations}

abs absorption chiller

coal coal
com compressor chiller
el electricity
G generator
$\mathrm{H}$ heat
F fuel
me mechanical energy
mix electricity mix
$P \quad$ primary energy
trigen trigeneration

\section{REFERENCES}

[1] Standard EN 15316-4-5:2006. Heating systems in buildings - method for calculation of system energy requirements and system efficiencies - part 4-5 space heating generation systems, the performance and quality of district heating and large volume systems. European Standardization Organizations (CEN), Brussels.

[2] Directive 2012/27/EU of the European Parliament and of the Council of 25 october 2012 on energy efficiency, amending directives 2009/125/EC and 2010/30/EU and repealing directives 2004/8/EC and 2006/32/EC text with EEA relevance, oj / 315, 14.11.2012, p. 1-56.

[3] Directive 2010/31/EU of the European Parliament and of the Council of 19 may 2010 on the energy performance of buildings, oj I 153, 18.6.2010, p. 124-146.

[4] Directive 2009/28/EC of the European Parliament and of the Council on the promotion of the use of energy from renewable sources and amending and subsequently repealing directives 2001/77/EC and 2003/30/EC, oj I/eut I 140, 23 april 2009, p. 16-47.

[5] Standard EN 15203/15315:2006. Energy performance od buildings-overall energy use, $\mathrm{CO}_{2}$ emissions and definition of energy ratings. European Committee for Standardization (CEN), Brussels.

[6] Standard EN 15603:2008. Energy performance of buildingsoverall energy use and definition of energy ratings. European Committee for Standardization (CEN), Brussels.

[7] Beretta, G.P., Iora, P., Ghoniem, A.F. (2012). Novel approach for fair allocation of primary energy consumption among cogenerated energy-intensive products based on the actual local area production scenario. Energy, vol. 44, no. 1, p. 11071120, D0l:10.1016/j.energy.2012.04.047.

[8] Laverge, J., Janssens, A. (2012). Heat recovery ventilation operation traded off against natural and simple exhaust ventilation in Europe by primary energy factor, carbon dioxide emission, household consumer price and exergy. Energy and Buildings, vol. 50, p. 315-323, Dol:10.1016/j. enbuild.2012.04.005.

[9] Wilby, M.R., Rodríguez González, A.B., Vinagre Díaz, J.J. (2014). Empirical and dynamic primary energy factors. Energy, vol. 73, p. 771-779, D0l:10.1016/j.energy.2014.06.083.

[10] Schicktanz, M.D., Wapler, J., Henning, H.-M. (2011). Primary energy and economic analysis of combined heating, cooling and power systems. Energy, vol. 36, no. 1, p. 575-585, DOI:10.1016/j.energy.2010.10.002. 
[11] Fumo, N., Chamra, L.M. (2010). Analysis of combined cooling, heating, and power systems based on source primary energy consumption. Applied Energy, vol. 87, no. 6, p. 2023-2030, D0l:10.1016/J.apenergy.2009.11.014.

[12] Mago, P.J., Chamra, L.M. (2009). Analysis and optimization of CCHP systems based on energy, economical, and environmental considerations. Energy and Buildings, vol. 41, no. 10, p. 1099-1106, D0l:10.1016/j.enbuild.2009.05.014.

[13] Wirgentius, N. (2006). Primary resource factor- for systematic evaluation of heating and cooling options. Euroheat \& Power Industry and Utility Forum, Vilnius.

[14] Dalla Rosa, A.; Christensen, J.E. (2011). Low-energy district heating in energy-efficient building areas. Energy, vol. 36, no. 12, p. 6890-6899, D0I:10.1016/j.energy.2011.10.001.

[15] Prandin, M. (2010). Exergy analysis at the community level: Matching supply and demand of heat and electricity in residential buildings. MSc. Project, KTH-Royal Institute of Technology, Stockholm.

[16] Życzyńska, A. (2013). The primary energy factor for the urban heating system with the heat source working in association. Eksploatacja i Niezawodność - Maintenance and Reliability, vol. 15, no. 4, p. 458-462.

[17] Jungbauer, J., Serrano Garcia, D., Wallisch, A., Dalin, P., Terouanne, D., Wirgentius, N. (2011). Measurements of individual chiller systems compared to district cooling solutions. ECEEE Conference Proceedings, Toulon.

[18] Riepl, M., Loistl, F., Gurtner, R., Helm, M., Schweigler, C. (2012). Operational performance results of an innovative solar thermal cooling and heating plant. Energy Procedia, vol. 30, p. 974-985, D0l:10.1016/j.egypro.2012.11.110.

[19] Dalin, P., Ivancic, A., Tvärne, A., Penthor, A., Martin, B., Ricci, F. (2006). District cooling-cooling more with less. Euroheat Power, vol. 32, p. 26-27.

[20] Makita, K. (2008). Waste heat energy application for absorption chillers. $3^{\text {rd }}$ International District Cooling Conference \& Trade Show, Dubai,

[21] Werner, S. (2006). Guidelines for assessing the efficiency of district heating and district cooling system. EUROHEATCOOL Work package 3, vol. 3, p. 13.

[22] Pout, C. (2011). Proposed carbon emission factors and primary energy factors for SAP 2012. Technical papers supporting SAP 2012, Building Research Establishment, Watford.

[23] Li, Y. (2012). Operation proposal and efficiency analysis of direct-fire absorption chillers biogas produced in the brewer. World Renewable Energy Forum, Denver.

[24] Börjesson, P., Prade, T., Lantz, M., Björnsson, L. (2015). Energy crop-based biogas as vehicle fuel-the impact of crop selection on energy efficiency and greenhouse gas performance. Energies, vol. 8, no. 6, p. 6033-6058, D0l:10.3390/ en8066033.

[25] Sweden Green Building Council (2014). Treatment of scandinavian district energy systems in LEED. Energy models gor LEED EA credit 1, Sweden Green Building Council, Stockholm.

[26] Poredos, A.; Kitanovski, A. (2011). District heating and cooling for efficient energy supply. International Conference on Electrical and Control Engineering Conference proceeding, p. 5238-5241, Yichang, DOl:10.1109/iceceng.2011.6058201.
[27] Kawasaki Thermal Engineering Co., L. (2014). Absorption Chillers Application and Efficiency, from http://www.khi.co.jp/ corp/kte, accessed on 2016-06-16.

[28] Ponomarev, P., Minav, T., Åman, R., Luostarinen, L. (2015). Integrated electro-hydraulic machine with self-cooling possibilities for non-road mobile machinery. Strojniški vestnik Journal of Mechanical Engineering, vol. 61, no. 3, p. 207-213, D0l:10.5545/sv-jme.2014.2017.

[29] Lozano, D.E, Martinez-Cazares, G., Mercado-Solis, R. D., Colás, R., Totten, G.E. (2015). Estimation of transient temperature distribution during quenching, via a parabolic model. Strojniški vestnik - Journal of Mechanical Engineering, vol. 61, no. 2, p. 107-114, DOI:10.5545/sv-jme.2014.1997.

[30] Rosen, M.A., Le, M.N., Dincer, I. (2005). Efficiency analysis of a cogeneration and district energy system. Applied Thermal Engineering, vol. 25, no. 1, p. 147-159, Dol:10.1016/j. applthermaleng.2004.05.008.

[31] Rezaie, B., Rosen, M.A. (2012). District heating and cooling: Review of technology and potential enhancements. Applied Energy, vol. 93, p. 2-10, Dol:10.1016/J.apenergy.2011.04.020.

[32] Patel, C.T., Patel, B., Patel, V.K. (2013). Efficiency with different gcv of coal and efficiency improvement opportunity in boiler. International Journal of Innovative Research in Science, Engineering and Technology, vol. 2, no. 5, p. 1518-1527.

[33] Durkin, T.H. (2006). Boiler system efficiency. ASHRAE Journal, vol. 48 , no. 7 , p. 51-57.

[34] Dobersek, D., Goricanec, D. (2009). Optimisation of tree path pipe network with nonlinear optimisation method. Applied Thermal Engineering, vol. 29, no. 8, p. 1584-1591, D0l:10.1016/j.applthermaleng.2008.07.017.

\section{APPENDIX A}

The ratio between the primary energy input of different cooling technologies and the primary energy input for the case of cooling with electrically driven compressor chillers $\left(P E F_{e l}=2.5\right)$ is presented in Fig. A1. The primary energy input is calculated by rearranging the Eq. (1):

$$
Q_{P}=P E F_{D C} \cdot Q_{D C},
$$

and the ratio is calculated as:

$$
\frac{Q_{P_{i}}}{Q_{P, C C_{\text {mix. } . P E F=2.5}}}=\frac{P E F_{D C, i}}{P E F_{C C_{\text {mix. } . P E F=2.5}}} .
$$

$P E F_{D C}$ at given conditions for different cooling technologies are given in Table A1. 


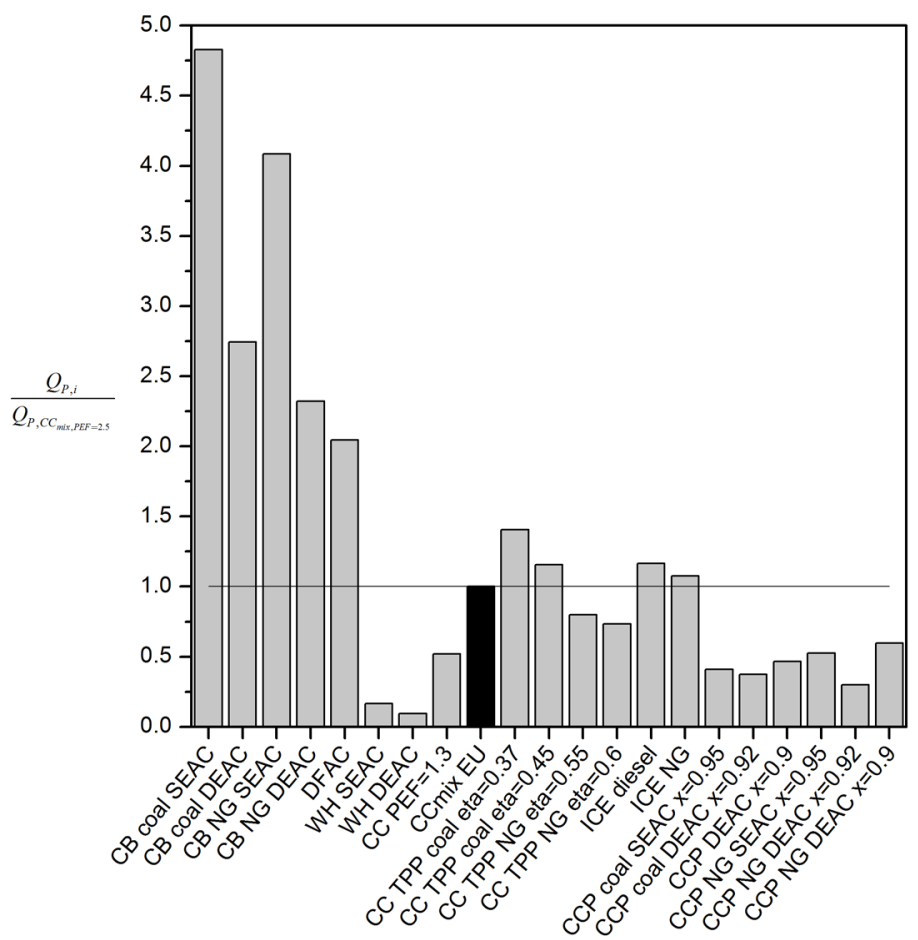

Fig. A1. The primary energy input of different cooling technologies compared to the primary energy input when cooling with electrically driven compressor chillers $\left(P E F_{\text {el }}=2.5\right)$

Table A1. PEFDC for different types of cooling technologies

\begin{tabular}{|c|c|c|}
\hline $\begin{array}{l}\text { Type of cooling } \\
\text { technology }\end{array}$ & General Eq. for $P E F_{D C, i}$ & $P E F_{D C}$ \\
\hline \multirow{4}{*}{$\mathrm{CB}$} & \multirow{4}{*}{$\cdot P E F_{F}$} & $P E F_{D C, C B_{S E A C, \text { coal }}}=\left(\frac{1}{0.79 \cdot 0.9 \cdot 0.9}\right) \cdot 1.3=2.03$ \\
\hline & & $P E F_{D C, C B_{D E A C, \text { coal }}}=\left(\frac{1}{1.39 \cdot 0.9 \cdot 0.9}\right) \cdot 1.3=1.15$ \\
\hline & & $P E F_{D C, C B_{S E A C, N G}}=\left(\frac{1}{0.79 \cdot 0.9 \cdot 0.9}\right) \cdot 1.1=1.72$ \\
\hline & & $P E F_{D C, C B_{D E A C, N G}}=\left(\frac{1}{1.39 \cdot 0.9 \cdot 0.9}\right) \cdot 1.1=0.98$ \\
\hline DFAC $_{\mathrm{NG}}$ & $P E F_{D C, N G}=\left(\frac{1}{C O P_{D F A C} \cdot \eta_{D N}}\right) \cdot P E F_{N G}$ & $P E F_{D C, N G}=\left(\frac{1}{1.42 \cdot 0.9}\right) \cdot 1.1=0.86$ \\
\hline$y$ & 1 & $P E F_{D C, W H, S E A C}=\left(\frac{1}{0.79 \cdot 0.9}\right) \cdot 0.05=0.07$ \\
\hline & $\left.C O P_{a b s} \cdot \eta_{D N}\right)$ & $P E F_{D C, W H, D E A C}=\left(\frac{1}{1.39 \cdot 0.9}\right) \cdot 0.05=0.04$ \\
\hline
\end{tabular}




\begin{tabular}{|c|c|c|}
\hline $\mathrm{CC}$ & $1) \cdot P E F$ & $P E F_{D C, C C_{m i x, P E F=2.5}}=\left(\frac{1}{6.6 \cdot 0.9}\right) \cdot 2.5=0.42$ \\
\hline & $\left(C O P_{c o m} \cdot \eta_{D N}\right)^{D C, C C_{\text {mix }}} \quad(e l, m i x$ & $P E F_{D C, C C_{m i x, P E F=1.3}}=\left(\frac{1}{6.6 \cdot 0.9}\right) \cdot 1.3=0.22$ \\
\hline \multirow{4}{*}{$\mathrm{CC}_{\mathrm{TPP}}$} & \multirow{4}{*}{$\cdot P E F_{F}$} & $P E F_{D C, C C_{T P P, \text { coal }, \eta=0.37}}=\left(\frac{1}{6.6 \cdot 0.9 \cdot 0.37}\right) \cdot 1.3=0.59$ \\
\hline & & $P E F_{D C, C C_{T P P, c o a l, \eta=0.45}}=\left(\frac{1}{6.6 \cdot 0.9 \cdot 0.45}\right) \cdot 1.3=0.49$ \\
\hline & & $P E F_{D C, C C_{T P P, N G, \eta=0.55}}=\left(\frac{1}{6.6 \cdot 0.9 \cdot 0.55}\right) \cdot 1.1=0.34$ \\
\hline & & $P E F_{D C, C C_{T P P, N G, \eta=0.60}}=\left(\frac{1}{6.6 \cdot 0.9 \cdot 0.60}\right) \cdot 1.1=0.31$ \\
\hline \multirow{2}{*}{ ICE } & \multirow{2}{*}{$P E F_{F}$} & $P E F_{D C, C C_{I C E, \text { diesel }}}=\left(\frac{1}{2.7 \cdot 0.9}\right) \cdot 1.19=0.49$ \\
\hline & & $P E F_{D C, C C_{I C E, N G}}=\left(\frac{1}{2.7 \cdot 0.9}\right) \cdot 1.1=0.31$ \\
\hline \multirow{6}{*}{$\mathrm{CCP}$} & \multirow{6}{*}{$P E F_{D C, C C P}=\frac{P E F_{F} \cdot(1-x)}{C O P_{a b s} \cdot \eta_{D N}} \cdot \frac{1}{\left(\eta_{C C P, \text { total }}-\eta_{C C P, e l}\right)}$} & $P E F_{D C, C C P_{S E A C, \text { coal } x=0.95}}=\frac{1.3(1-0.95)}{0.79 \cdot 0.9 \cdot(0.9-0.37)}=0.17$ \\
\hline & & $P E F_{D C, C C P_{D E A C, \text { coal } x=0.92}}=\frac{1.3(1-0.92)}{1.39 \cdot 0.9 \cdot(0.9-0.37)}=0.16$ \\
\hline & & $P E F_{D C, C C P_{D E A C, \text { coal } x=0.90}}=\frac{1.3(1-0.90)}{1.39 \cdot 0.9 \cdot(0.9-0.37)}=0.20$ \\
\hline & & $P E F_{D C, C C P_{S E A C, N G, x=0.95}}=\frac{1.1 \cdot(1-0.95)}{0.79 \cdot 0.9 \cdot(0.9-0.55)}=0.22$ \\
\hline & & $P E F_{D C, C C P_{D E A C, N G, x=0.92}}=\frac{1.1(1-0.92)}{1.39 \cdot 0.9 \cdot(0.9-0.55)}=0.13$ \\
\hline & & $P E F_{D C, C C P_{D E A C, N G, x=0.90}}=\frac{1.1 \cdot(1-0.90)}{1.39 \cdot 0.9 \cdot(0.9-0.55)}=0.25$ \\
\hline
\end{tabular}

